

\title{
A study of AlN-Si3N4 codeposits using the L.P.C.V.D. technique
}

\author{
F. Henry, B. Armas, M. Balat, R. Berjoan, C. Combescure
}

\section{To cite this version:}

F. Henry, B. Armas, M. Balat, R. Berjoan, C. Combescure. A study of AlN-Si3N4 codeposits using the L.P.C.V.D. technique. Journal de Physique IV Proceedings, 1993, 03 (C3), pp.C3-519-C3-526. 10.1051/jp4:1993372 . jpa-00251429

\section{HAL Id: jpa-00251429 https://hal.science/jpa-00251429}

Submitted on 1 Jan 1993

HAL is a multi-disciplinary open access archive for the deposit and dissemination of scientific research documents, whether they are published or not. The documents may come from teaching and research institutions in France or abroad, or from public or private research centers.
L'archive ouverte pluridisciplinaire HAL, est destinée au dépôt et à la diffusion de documents scientifiques de niveau recherche, publiés ou non, émanant des établissements d'enseignement et de recherche français ou étrangers, des laboratoires publics ou privés. 


\title{
A study of $\mathrm{AIN}_{-\mathrm{Si}_{3} \mathrm{~N}_{4}}$ codeposits using the L.P.C.V.D. technique
}

\author{
F. HENRY, B. ARMAS, M. BALAT, R. BERJOAN and C. COMBESCURE
}

Institut de Science et de Génie des Matériaux et Procédés, CNRS-IMP, BP. 5, Odeillo, 66125 Font Romeu cedex, France

\begin{abstract}
:
We have studied the codeposition of aluminum nitride and silicon nitride, using aluminum trichloride and silicon tetrachloride as vectors of aluminum and silicon respectively, ammonia as source of nitrogen, and nitrogen as carrier gas. A preliminary thermodynamic study allowed us to determine the influence of pressure, temperature and gas composition on the Al, Si, N, H, Cl system. Particularly, we have shown that the Al/Si ratio as well as the quantity of ammonia play a crucial role in the composition of the codeposit. An experimental study has been carried out using a hot-wall reactor. At $1253 \mathrm{~K}$ with a pressure of $133 \mathrm{~Pa}$, we have obtained deposits varying from $A 1 N$ to $\mathrm{Si}_{3} \mathrm{~N}_{4}$, via intermediate compositions, by varying the reactive gas mixture. The codeposits have been characterized using various methods such as X-ray diffraction, Auger, X.P.S., S.E.M. and E.P.M.A..
\end{abstract}

\section{INTRODUCTION}

For many years the aluminum and silicon nitrides have presented great interest as ceramic materials for high temperature and electronic applications.

AlN and $\mathrm{Si}_{3} \mathrm{~N}_{4}$ are often used in thin solid films on electronic devices $[1,2]$.

Among the thin coating methods for these materials, the low pressure chemical vapour deposition (L.P.C.V.D.) is one of the most attractive $[3,4]$.

our laboratory has more than twenty years of experience in the field of L.P.C.V.D. and particularly on the vapour deposition of $A \perp N$ and $\mathrm{Si}_{3} \mathrm{~N}_{4}[5,6]$.

In the aim of having materials with new properties such as a better oxidation resistance than either AlN or $\mathrm{Si}_{3} \mathrm{~N}_{4}$ taken separately, we have thought to make codeposits, and we have entered upon a study of the Al-Si-N system.

sytem.

In the literature, few works have been already done on this

HILLERT and al. [7] have done an interesting theoretical work on the Al-Si-N system considering the pseudo binary $\mathrm{Si}_{3} \mathrm{~N}_{4}-\mathrm{AlN}$.

A more general study on the ternary systems $M-S i-N$ (with $M=$ $\mathrm{Al}, \mathrm{Cu}, \mathrm{Zn} . .$.$) was done by WEITZER and al [8]. Their results suggest$ that no ternary phase is present in the Al-Si-N system, neither a 
solid solution.

From the experimental point of view, ZIRINSKY and al. [9] reported previously other results concerning the mixed deposition of aluminum and silicon nitrides on silicon and sapphire substrates between 600 and $1100^{\circ} \mathrm{C}$ by ammoniolysis of aluminum trichloride and silane. These authors showed that the deposit kinetics and the thickness uniformity is influenced by the ratio $\mathrm{NH}_{3} /\left(\mathrm{AlCl}_{3}, \mathrm{SiCl}_{4}\right)$, but no thermodynamic approach was made.

our contribution consists in doing first a thermodynamic predictive calculation, and secondly an experimental study with a characterization of the vapour deposited coatings.

We propose the synthesis of these two compounds $\mathrm{AlN}$ and $\mathrm{Si}_{3} \mathrm{~N}_{4}$ using chemical vapor deposition with aluminum trichloride, silicon tetrachloride, ammonia and hydrogen as chemical precursors.

\section{THERMODYNAMIC STUDY}

Before an experimental elaboration of such materials, it is necessary to do a theoretical calculation to know the better conditions for $\mathrm{AIN}$ and $\mathrm{Si}_{3} \mathrm{~N}_{4}$ codeposits.

The equilibrium calculation is based upon the Gibbs free energy minimization method in a closed system. We use the SOLGASMIX program, developped by ERIKSSON [10] which calculates both vapour and solid phase compositions when equilibrium is reached at given temperature and total pressure.

For this system, the variance is equal to 3 . So when $P$ and $T$ are fixed, the degree of freedom is one, so we have to fix, for example, a composition ratio.

The deposit is considered as being in equilibrium with the vapour phase. It is also assumed that the substrate is chemically inert with respect to the deposit and the vapour phase, and that all the chemical species which can be present at the equilibrium are known and taken into account in the calculations.

With our precursors, we consider the system $\mathrm{Al}, \mathrm{Si}, \mathrm{Cl}$, and $\mathrm{H}$ - Thus 38 species are taken (Table 1 ).

The thermodynamic data used for the calculation are taken from JANAF tables [11].

The domain of investigation is restricted to : $2.510^{-2} \leq$ $\mathrm{NH}_{3} /\left(\mathrm{AlCl}_{3}+\mathrm{SiCl}_{4}\right) \leq 4.10^{2}, 1100 \leq \mathrm{T} \leq 1500 \mathrm{~K}$ and $100 \leq \mathrm{P}_{\mathrm{T}} \leq 10^{4} \mathrm{~Pa}$. The chemical species initially introduced into the calculations either react totally at equilibrium to give new species or remain partially unreacted.

The results are formulated as thermodynamic yield $\left(y_{x}\right)$ defined as the ratio between the input mole number of species $x$ ( $x_{i n}$ ) to the mole number of the parent species at equilibrium $\left(x_{e q}\right)$ taking into account the stoechiometric coefficient. For example:

$$
\begin{aligned}
& \mathrm{Y}_{\mathrm{A} \backslash \mathrm{N}}=\mathrm{AlN}_{\mathrm{eq}} / \mathrm{AlCl}_{3 \mathrm{in}} \\
& \mathrm{Y}_{\mathrm{Si} \mathrm{NN} 4}=3 \mathrm{Si}_{3} \mathrm{~N}_{4 \mathrm{eq}} / \mathrm{SiCl}_{4 \text { in }} \\
& \mathrm{Y}_{\mathrm{HCl}}=\mathrm{HCl}_{\mathrm{eq}} / 7\left(\mathrm{AlCl}_{3}+\mathrm{SiCl}_{4}\right)_{\text {in }}
\end{aligned}
$$

\subsection{Yields variation with temperature}

The variations of the $A 1 N$ and $S i_{3} N_{4}$ yields with temperature are shown on Figures 1 and 2 for a maximum final mixing of $75 \% \mathrm{AlN}+$ 25\% $\mathrm{Si}_{3} \mathrm{~N}_{4}$ for two pressures : 500 and $10^{4} \mathrm{~Pa}$.


$+\mathrm{SiCl}_{4}$ ) value is in the range 20-160. However, $\mathrm{Y}_{\mathrm{A}}$ (N decreases with decreasing the last ratio. 
This behaviour is amplified by decreasing the pressure. Indeed, on Figure $2(P=500 \mathrm{~Pa})$, for temperatures upper than $1400^{\circ} \mathrm{C}$, the AlN yield is nearly zero.

\subsection{Yields variation with the molar ratio $\mathrm{NH}_{3} /\left(\mathrm{AlCl}_{3}+\mathrm{SiCl}_{4}\right)$}

On Figures 3 and 4 , the $A l N$ and $\mathrm{Si}_{3} \mathrm{~N}_{4}$ yields are given versus the molar ratio $\mathrm{NH}_{3} /\left(\mathrm{AlCl}_{3}+\mathrm{SiCl}_{4}\right)$ for a total pressure of $10^{4} \mathrm{~Pa}$ and for two temperatures of 1300 and $1500 \mathrm{~K}$.

At this pressure, whatever is the temperature, the AIN formation only appears for a molar ratio upper than 20 as the $\mathrm{Si}_{3} \mathrm{~N}_{4}$ one starts at 0.050 .

Moreover, the AlN formation only starts when nearly all the $\mathrm{Si}_{3} \mathrm{~N}_{4}$ is formed.

For the lower pressure of $500 \mathrm{~Pa}$, Figures 5 (for $1300 \mathrm{~K}$ ) and 6 (for $1400 \mathrm{~K}$ ) show the same tendancy, but the formation of AlN is never complete and for $1500 \mathrm{~K}$, there is no AlN elaborated.

We can see that when the AlN yield decreases the Alcl yield is very high.

In conclusion, this thermodynamic study shows that it is necessary to have a great molar ratio $\mathrm{NH}_{3} /\left(\mathrm{AlCl}_{3}+\mathrm{SiCl}_{4}\right)$ to prepare $\mathrm{AlN}$ and $\mathrm{Si}_{3} \mathrm{~N}_{4}$ whatever are the pressure and temperature constraints.

\section{EXPERIMENTAL STUDY}

The experimental system used is a vertical hot wall reactor composed of a graphite susceptor heated by high frequency induction. Source gases were aluminum trichloride $\mathrm{AlCl}_{3}$, silicon tetrachloride $\mathrm{SiCl}_{4}$, ammonia $\mathrm{NH}_{3}$ and nitrogen $\mathrm{N}_{2}$ as a carrier gas. The $\mathrm{AlCl}_{3}$ contained in an evaporator, was heated by a wire heater and carried by nitrogen. The $\mathrm{SiCl}_{4}$ contained in another evaporator is heated at $313 \mathrm{~K}$ (vapour pressure $\sim 54.10^{3} \mathrm{~Pa}$ ). All gas connections were thermally insulated to prevent any condensation. The ammonia was injected separately from the other reactive gases to avoid a reaction between them before the reaction zone. A graphite sample protected by a BSiC layer deposited by L.P.C.V.D. was used as substrate.

The deposition was tried using the following conditions: temperature $1253 \mathrm{~K}$ to $1373 \mathrm{~K}$, pressure $133 \mathrm{~Pa}$; gas phase composition $\mathrm{NH}_{3} /\left(\mathrm{AlCl}_{3}+\mathrm{SiCl}_{4}\right)=1$ to $60 ; \mathrm{N}_{2}$ flowrate $\mathrm{D}=8.10^{3} \mathrm{~cm}^{3} \cdot \mathrm{h}^{-1}$.

\section{Codeposits characterization}

The chemical compositions of the codeposits were first determined by an Electron Probe Micro-Analysis (E.P.M.A.) CAMECA using Wavelength Dispersive System (W.D.S.). Various compositions of the codeposits were evidenced in all the pseudo-binary composite range between pure $\mathrm{AIN}$ and pure $\mathrm{Si}_{3} \mathrm{~N}_{4}$. The codeposits contain only some traces of chlorine and less than $2 \%$ atomic of oxygen and carbon. These low carbon and oxygen amounts can be attributed to surface contamination, or to some porosity.

The codeposits obtained at $1253 \mathrm{~K}$ were analyzed by X-Ray Diffraction. For the materials with very low silicon contents ( 1 to $2 \%$ ) the X.R.D. spectra present narrow diffraction peaks corresponding to a crystallized AlN phase. Nevertheless, the X.R.D. peaks are broadened with increasing the silicon content in the deposits. For $S i$ contents higher than $15 \%$ atomic concentration, the X.R.D. spectra are similar to those of amorphous compounds.

The surface morphology of the deposits has been examined by Scanning Electron Microscopy (S.E.M.) : the codeposits with high AlN content present a polycrystaline structure with well defined 
microcrystals (Fig.7), which agrees with the characteristic growth of AlN from $\mathrm{AlCl}_{3}$ and $\mathrm{NH}_{3}$ gas precursors [12]. A morphological change is observed with increasing the silicon content in the codeposit. Indeed, the sharp edges observed for pure AlN disappear progressively with increasing the silicon content in the solid. Progressively, the surface acquires a "cauliflower" aspect (Fig.8). Polished cross section show that the codeposit has a good adhesion on the silicon carbide substrate (Fig.9).

An AlN $-\mathrm{Si}_{3} \mathrm{~N}_{4}$ codeposit $(\mathrm{Al}: 22 \%, \mathrm{Si}: 24 \%, \mathrm{~N}: 53.6 \%, 0$ : $0.4 \%$ ) has been characterized by $X$-Ray Photoelectron Spectroscopy (X.P.S.) using a CAMECA RIBER AUGER X.P.S. device.

Charging effects involving charge shift were observed on this insulating material. However, chemical bondings informations could be obtained by measuring the modified Auger parameter $\alpha^{\prime}$ for silicon and for aluminum.

The Auger parameter $\alpha^{\prime}$ is the difference between the Si KLL (or Al KLL) Iine kinetic energy and the $\mathrm{si} 2 \mathrm{p}$ (or $\mathrm{Al} 2 \mathrm{p}$ ) photoelectron line kinetic energy, plus the energy of the Al Ka exciting radiation.

$$
\alpha^{\prime}=E_{k}(S i \mathrm{KLL})-E_{k}(\mathrm{Si} 2 \mathrm{p})+1486.6 \mathrm{eV}
$$

This parameter is not subject to steady charge effects.

The X.P.S. spectrum obtained for this codeposit is shown on Figure 10 .

The $\alpha^{\prime}$ values measured for $\mathrm{Si}$ and $\mathrm{Al}$ are the following ones :

$\alpha^{\prime}(S i)=1714.6 \pm 0.2 \mathrm{eV}, \alpha^{\prime}(\mathrm{Al})=1463 \pm 0.2 \mathrm{eV}$.

For $\mathrm{Si}_{3} \mathrm{~N}_{4}$, some authors reported the $\alpha^{\prime}$ values :

$1714.1 \mathrm{eV}$ [13] and $1714.6 \mathrm{eV}$ [14]. obtained :

Two reference $\mathrm{Si}_{3} \mathrm{~N}_{4}$ samples were examined in this work. We

$\alpha^{\prime}(\mathrm{Si})=1714.6 \pm 0.2 \mathrm{eV}$.

For $A 1 N$, the $\alpha^{\prime}$ value given elsewhere is :

$\alpha^{\prime}=1462.9 \mathrm{eV}$.

The Auger parameters measured for the AI-Si-N codeposit match very well the Auger parameters measured for $A I N$ and $S i_{3} N_{4}$ compounds. Therefore, we could conclude that this codeposit is presumably and $\mathrm{AlN}-\mathrm{Si}_{3} \mathrm{~N}_{4}$ mixture.

\section{CONCLUSION}

The thermodynamical study reported in this work has demonstrated that the formation of $A l N-\mathrm{Si}_{3} \mathrm{~N}_{4}$ codeposits requires high molar ratios $\mathrm{NH}_{3} /\left(\mathrm{AlCl}_{3}+\mathrm{SiCl}_{4}\right)$.

Then, an experimental $\mathrm{AlN}-\mathrm{Si}_{3} \mathrm{~N}_{4}$ codeposition trial in a CVD hot-wall reactor demonstrated the formation of these codeposits in all the composition range between pure $\mathrm{AlN}$ and pure $\mathrm{Si}_{3} \mathrm{~N}_{4}$. The W.D.S. and X.P.S. characterizations of one deposit containing equal amounts of aluminum and silicon resulted in the conclusion that these codeposits contain $\mathrm{AIN}$ and $\mathrm{Si}_{3} \mathrm{~N}_{4}$ mixtures.

This paper reports a preliminary experimental study of the Al-Si-N codeposits elaboration by L.P.C.V.D. We would investigate now the influence of various experimental conditions on the composition 
and on the microstructures of the codeposits.

\section{ACKNOWLEDGEMENTS}

This work has been supported by the French Ministry of Defense, Direction des Recherches et Etudes Techniques (Contrat DRET $\left.N^{\circ} 90 \quad 1197 A\right)$.

\section{REFERENCES}

[1] PAUleAU Y., HANTZPERGUE J.J., REMY J.C., Bull. Soc.Chim. Fr., 5-6 (1979) 199-214.

[2] MOROSANU C.E., Thin Solid Films, 65 (1980) 171.

[3] MELLOTTEE H., COCHET G., Rev. Int. Hautes Temp. et Réfract. 13 (1976) 31.

[4] ARMAS B., COMBEscure c., in "Proc. 10th. Int. Conf. CVD", published by the Electrochem. Soc. (1987) 1060.

[5] LARTIGUE J.F., DUCARROIR M., ARMAS B., in "Proc. $9^{t h}$. Int. Conf . CVD", published by the Electrochem.Soc. (1984) 561.

[6] ASPAR B., ARMAS B., COMBESCURE C., THENEGAL D., J. Eur. Ceram.SOC. 8 (1991) 251-256.

[7] HILLERT M., JONSSON S., CALPHAD, 16 (2) (1992) 199-205.

[8] WEITZER F., REMSCHNIG K., SCHUSTER J.C., ROGL P., J.Mater.Res., 8 (10) (1990) 2152-2159.

[9] ZIRINSKY S., IRENE E.E., J. Electrochem. Soc., 125 (2) (1978) 305-314.

[10] ERIKSSON G., Chemica Scripta, 8 (1975) 100-103.

[11] CHASE N.W., DAVIES C.A.Jr, DOWNEY J.R., FRURIP D.J., MCDONALD R.A., SYVERUD A.N., JANAF Thermochemical Tables, Third Edition, J.Phys.Chem.Ref.Data, 14 (1985) .

[12] ASPAR B., RODRIGUEZ - CLEMENTE R., FIGUERAS A., ARMAS B., COMBESCURE C., J. Crystal Growth, accepted.

[13] BORSELLA E., BOTTI S., FANTONI R., ALEXANDRESCU R., MORJAN I, POPESCU C., DIKONIMOS-MAKRIS T., GIORGI R., ENZO S., J. Mater. Res., 7 (8) (1992) 2257-2268.

[14] BRIGGS D., SEAH M.P., Practical Surface Analysis, Ed. WILEY J. and Sons Ltd, Chichester (1983).

Table 1 : Chemical species introduced in the thermodynamic calculations ( $>$ solid, // liquid, gas).

\begin{tabular}{|c|c|c|c|c|c|c|}
\hline \multicolumn{7}{|c|}{ system A] } \\
\hline $\begin{array}{l}\mathrm{Al} \\
\mathrm{Al}_{2} \\
\mathrm{AlCl} \\
\mathrm{AlCl} 2 \\
\mathrm{AlCl}_{3} \\
\mathrm{Al}_{2} \mathrm{Cl}_{6}\end{array}$ & $\begin{array}{l}\mathrm{AlH} \text { AlN } \\
\mathrm{Cl} \\
\mathrm{Cl}_{2} \\
\mathrm{HCl} \\
\mathrm{H} \\
\mathrm{H}_{2}\end{array}$ & $\begin{array}{l}\quad \mathrm{N} \\
\mathrm{Si} \\
\mathrm{Si} \\
\mathrm{Si}_{3} \\
\mathrm{SiN} \\
\mathrm{Si}_{2} \mathrm{~N}\end{array}$ & $\begin{array}{c}\mathrm{N}_{2} \mathrm{H}_{4} \\
\mathrm{~N}_{2} \\
\mathrm{NH} \\
\mathrm{NH}_{2} \\
\mathrm{NH}_{3} \\
\mathrm{~N}_{2} \mathrm{H}_{2}\end{array}$ & $\begin{array}{c}\mathrm{SiH}_{2} \mathrm{Cl}_{2} \\
\mathrm{SiCl} \\
\mathrm{SiCl}_{2} \\
\mathrm{SiCl}_{3} \\
\mathrm{SiCl}_{4} \\
\mathrm{SiH}_{3} \mathrm{Cl}\end{array}$ & $\begin{array}{l}/ \mathrm{Al} / * \\
\mathrm{SiHCl}_{3} \\
\mathrm{SiH}_{3} \\
\mathrm{SiH}_{4}\end{array}$ & $\begin{array}{l}<\mathrm{Si}>* \\
<\mathrm{AlN}> \\
\left\langle\mathrm{Si}_{3} \mathrm{~N}_{4}>\right.\end{array}$ \\
\hline
\end{tabular}


$P=10^{4} \mathrm{~Pa}$

$\mathrm{NH}_{3} /\left(\mathrm{AlCl}+\mathrm{SiCl}_{4}\right)$ fixed

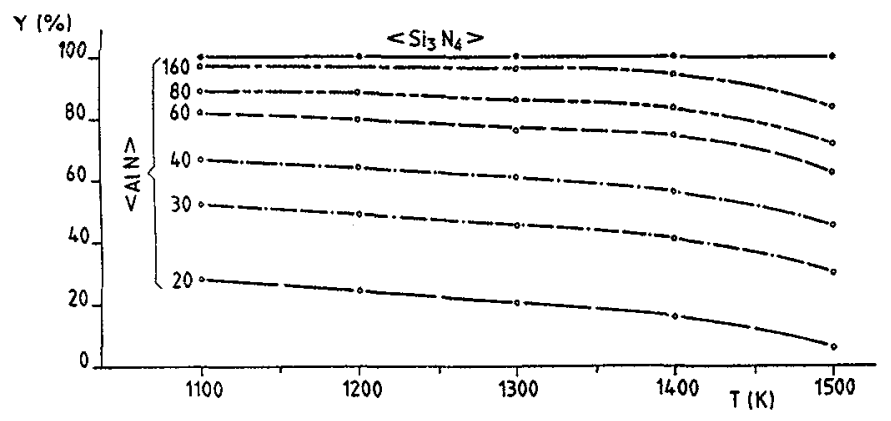

$P=500 \mathrm{~Pa}$

$\mathrm{NH}_{3} /\left(\mathrm{Al} \mathrm{Cl} l_{3}+\mathrm{Si} \mathrm{Cl}_{4}\right)$ fixed
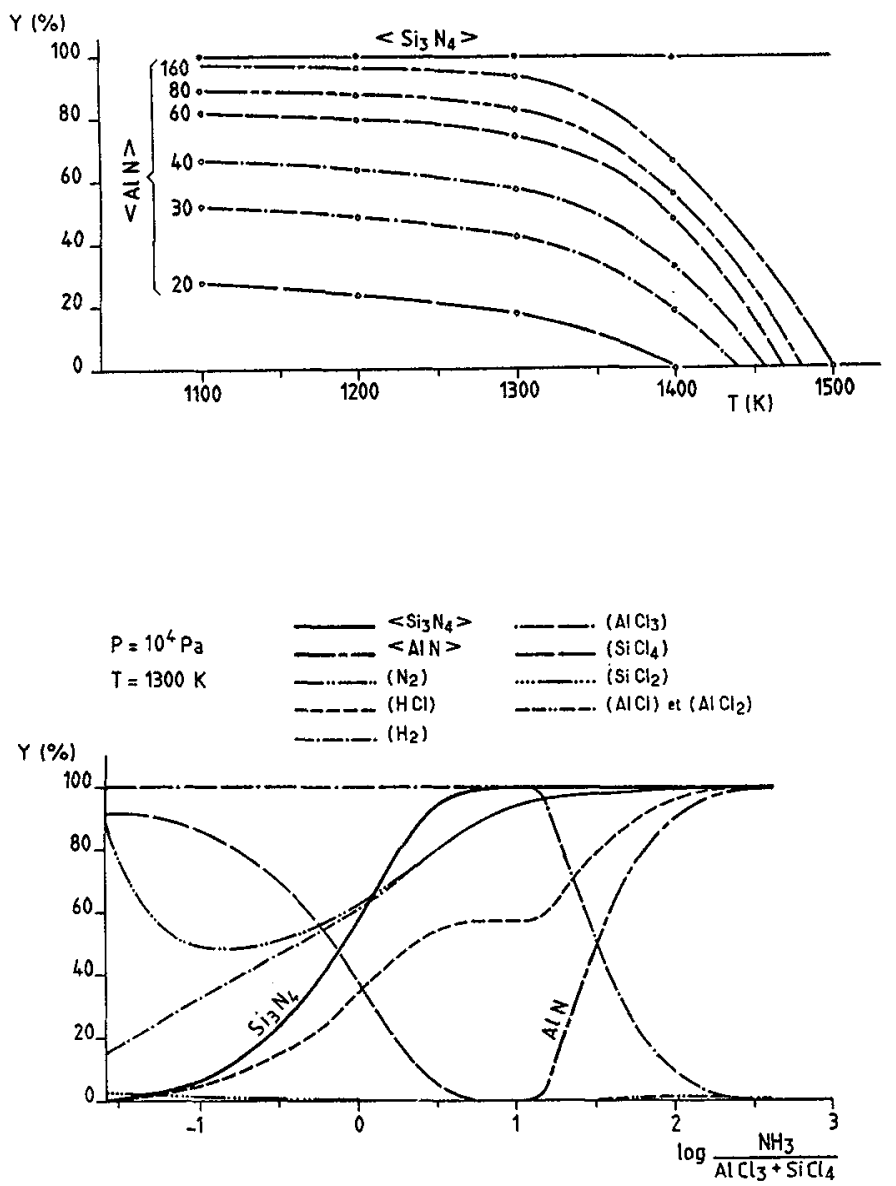

Figure 1: $\mathrm{Si}_{3} \mathrm{~N}_{4}$ and AlN yields versus temperature, with $\mathrm{P}=$ $10^{4} \mathrm{~Pa}$, for six molar ratios $\mathrm{NH}_{3} /\left(\mathrm{AlCl}_{3}+\right.$ $\mathrm{SiCl}_{4}$ ).

Figure 2: $\mathrm{Si}_{3} \mathrm{~N}_{4}$ and AlN yields versus temperature, with $\mathbf{P}=$ $500 \mathrm{~Pa}$, for six molar ratios $\mathrm{NH}_{3} /\left(\mathrm{AlCl}_{3}+\right.$ $\mathrm{SiCl}_{4}$ ).
Figure 3: Equilibrium yields variation versus the molar ratio $\mathrm{NH}_{3} /\left(\mathrm{AlCl}_{3}+\right.$ $\mathrm{SiCl}_{4}$ ), with $\mathrm{T}=1300$ $\mathrm{K}$ and $\mathrm{P}=10^{4} \mathrm{~Pa}$. 

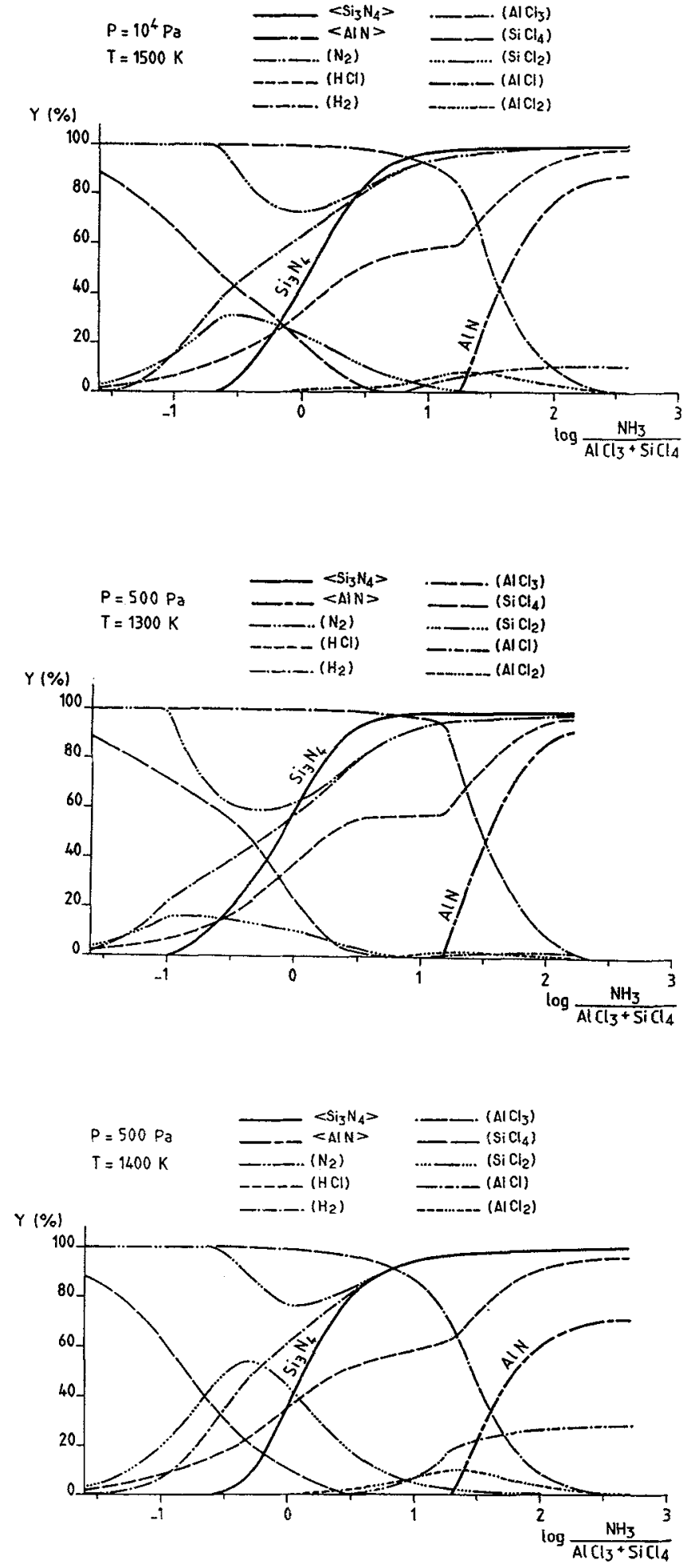

Figure 4: Equilibrium yields variation versus the molar ratio $\mathrm{NH}_{3} /\left(\mathrm{AlCl}_{3}+\right.$ $\mathrm{SiCl}_{4}$ ), with $\mathrm{T}=1500$ $K$ and $P=10^{4} \mathrm{~Pa}$.
Figure 5: Equilibrium yields variation versus the molar ratio $\mathrm{NH}_{3} /\left(\mathrm{AlCl}_{3}+\right.$ $\mathrm{SiCl}_{4}$ ), with $\mathrm{T}=1300$ $\mathrm{K}$ and $\mathrm{P}=500 \mathrm{~Pa}$.
Figure 6: Equilibrium yields variation versus of the molar ratio $\mathrm{NH}_{3} /\left(\mathrm{AlCl}_{3}+\right.$ $\mathrm{SiCl}_{4}$ ), with $\mathrm{T}=1400$ $\mathrm{K}$ and $\mathrm{P}=500 \mathrm{~Pa}$. 


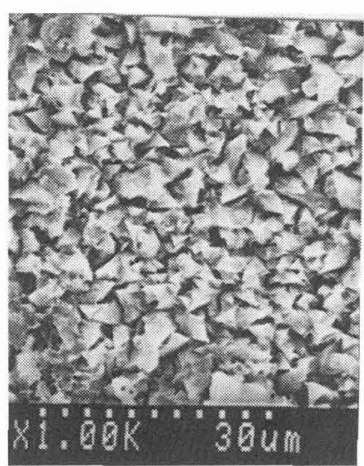

Figure 7 .

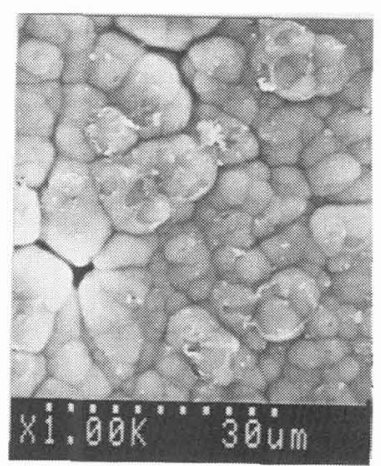

Figure 8.

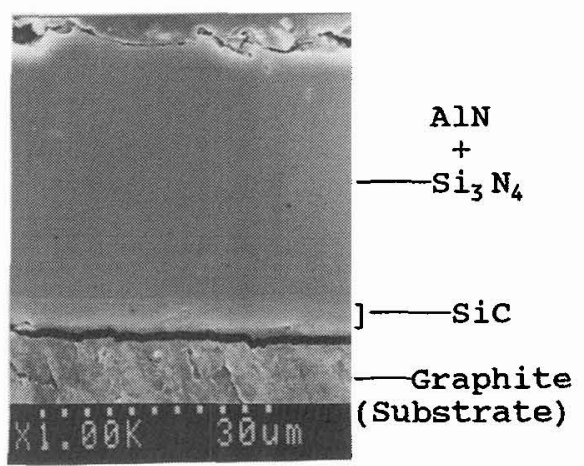

Figure 9.

Figure 7: SEM micrograph showing the morphology of $95 \% \mathrm{AlN}$ and

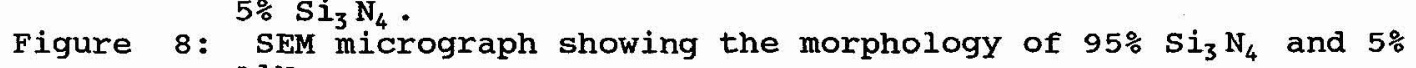
Figure 9: AEM micrograph showing a cross-section of the $\mathrm{AlN}-\mathrm{Si}_{3} \mathrm{~N}_{4}$ codeposit ( $95 \% \mathrm{AlN}$ and $5 \% \mathrm{Si}_{3} \mathrm{~N}_{4}$ ).

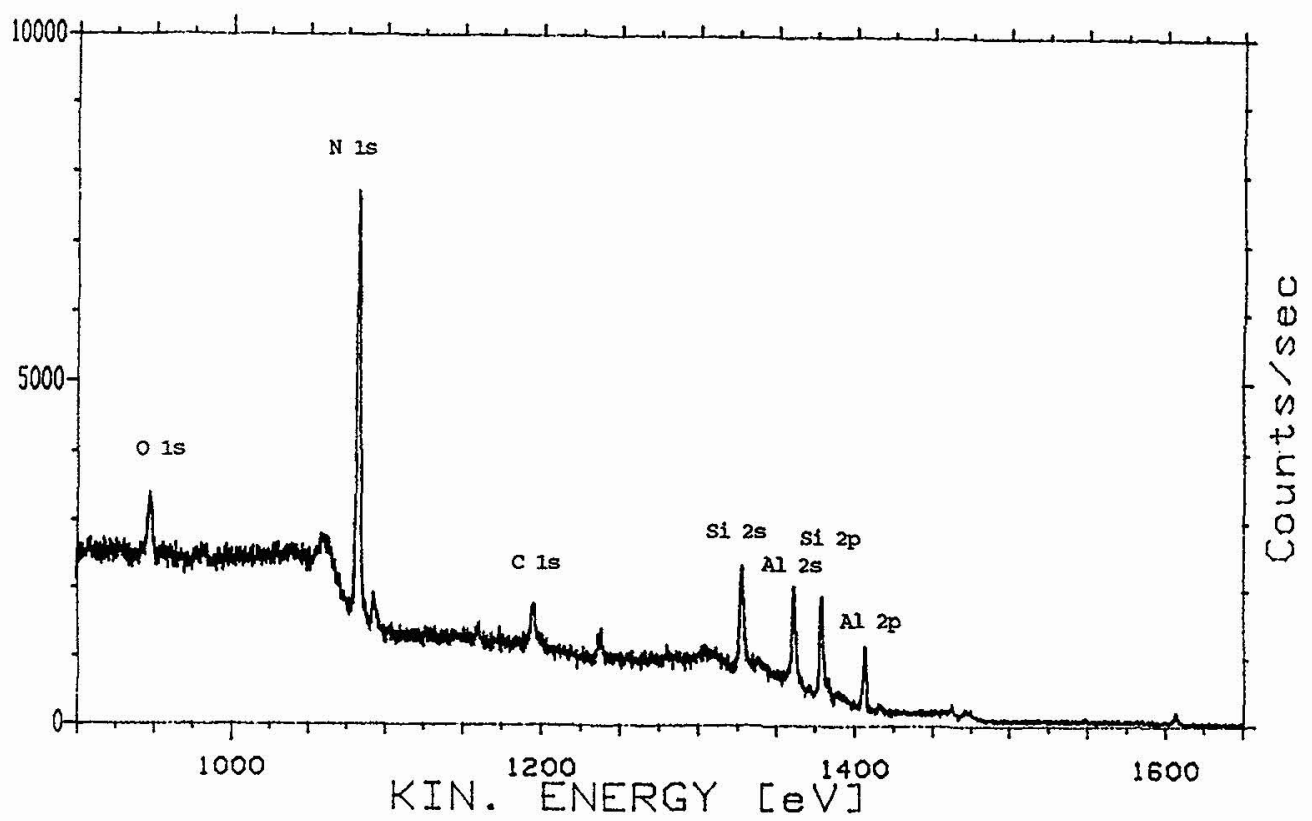

Figure 10 : X.P.S. spectrum obtained on experimental conditions : $\mathrm{T}=1253 \mathrm{~K}, \mathrm{P}=133 \mathrm{~Pa}$. 